
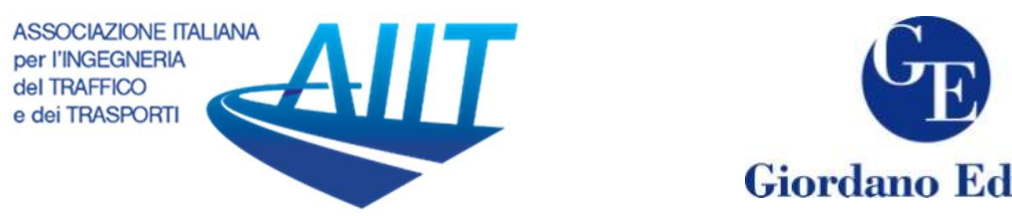

Giordano Editore

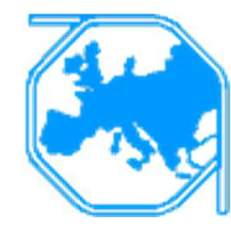

\title{
Measuring costs of noise pollution generated by freight transport: Case of the Slovak and Czech Republic
}

\author{
B. Andrlík ${ }^{1}$, M. Smékalová ${ }^{2}$ \\ ${ }^{1}$ Department of Accounting and Taxes, Faculty of Business and Economics, \\ Mendel University in Brno, Zemédělská 1, 61300 Brno, Czech Republic, \\ email:xandrlik@mendelu.cz \\ 2 Department of Accounting and Taxes, Faculty of Business and Economics, \\ Mendel University in Brno, Zemédělská 1, 61300 Brno, Czech Republic, \\ email:xsmeka@node.mendelu.cz
}

\begin{abstract}
The paper focuses on measuring and quantification of the negative externality of noise pollution generated by freight transport in the Slovak Republic and the Czech Republic. The paper describes negative impacts and significance of noise externalities, whereas it is established that noise causes psychological and physiological harm to affected persons. A separate part of the paper is dedicated to the current status of the European legislation dealing with the issues of the negative externality of noise pollution, in particular Directive 2002/49/EC of the European Parliament and of the Council and Communication COM(2008) 435. The actual measurement of the total, average and marginal costs of noise pollution is implemented in line with the defined methodology and using expert studies defined in the paper. The measurement results show that the costs of the negative externality of noise pollution are high in both countries. According to authors' calculations, the total costs of the negative externality of noise pollution amount to EUR 100.8 mil in the Czech Republic and EUR 16.9 mil in the Slovak Republic. The paper contains a proposal of internalisation of these costs in the form of performance charges applied to operation of heavy goods vehicles.
\end{abstract}

Keywords: noise, truck, external cost, negative externality, transport.

\section{Introduction}

Transport is one of the key sectors in modern market economies. According to ACEA (2016), the positive effect of transport is indisputable and its benefits include for example the creation of 12.1 mil. jobs or creation of added value for the European economy of EUR 550 billion due to freight transport. Besides its positive effects, transport also generates a number of negative ones. Operators of motor vehicles cause additional costs to society in general. According to Cnossen (2005) these negative externalities associated with transport include congestion, accidents, noise pollution, environmental pollution and wear and tear of transport infrastructure. Santos (2010) classifies negative externalities in a similar way and also states that these negative externalities are not included in market prices. According to Delucchi (2003), from the economic point of view, externalities are undesirable because if they exist, the originators of the harm may make decisions which 
would result in a situation when the social cost would exceed the yield. Generators then face incorrect stimuli regarding transport demand and offer which according to CE Delft (2008) results in social losses. In order to deal with these negative externalities, a state intervention is required into market mechanisms using fiscal tools, which eliminate the differences between the costs incurred by the society and the generators of the given externality (Rozehnalová at al., 2021). A proposal for corrective taxation for the purpose of internalisation of negative externalities was presented already by Pigou (1932). A practical model of an environmental tax using the case of the Slovak Republic was proposed by Palenik and Miklosovic (2018); it includes definitions of parameters of the impact of their tax. Johnson, Leicester and Stoye (2012) highlight other external costs which might be internalised by means of taxes, such as costs associated with noise pollution, costs of road maintenance and other environmental risks.

Ricardo AEA (2014) states that external costs of transport may be considered the difference between social costs (the costs which the transport transfers to its surroundings) and the actual costs of its users (vehicles wear, fuel costs, time costs, etc.). The issues of the actual costs are dealt with by Lebeau et al. (2013) and De Clerck et al. (2016), who point out that consumers should not focus only on initial acquisition costs but should also consider all costs associated with ownership of a vehicle. Ajanovic and Haas (2016) view the use of alternative and environmentally friendly drives and fuels in transport as the key direction when limiting the negative externality. They emphasize the need to introduce such measures which are critical particularly in big cities where noise pollution and emissions present an ever increasing problem. Similarly, Hamad at al. (2016) states that traffic noise is considered a major source of environmental pollution because it negatively affects human health.

Thus, with regard to personal costs of users, optimal fees in transport should reflect the costs of use of the given infrastructure - the costs of its wear and tear and overloading, environmental costs and costs of accidents. While road fees are regarded as a suitable tool for imposing charges for the use of the existing infrastructure and for many externalities of transport, according to CE Delft (2008) it is also suitable to include long-term objectives such as infrastructure expansion and reduction of emissions in road, environmental and excise taxes. EU member states often discuss internalisation of noise pollution negative externality as part of tax or non-tax tools. For example, according to Frouzova and Vachal (2019), the Minister of Transport of the Czech Republic stated in April 2019 that the Ministry of Transport of the CR was working on an amendment to Act No. 13/1997 Coll., on Roads, as a result of which noise external costs could be included in the calculation of the final rate of toll. The objective of this paper is to quantify the values of total, average and marginal costs of negative externality of noise pollution in the Czech Republic and the Slovak Republic in 2017 based on analysis and using expert research studies dealing with measurement of external costs. A partial objective is to recommend a suitable tool of state tax or fee policy allowing internalisation of the negative externality of noise pollution and at the same time to support defined objects and discussions of inclusion of these external costs based on the achieved results of cost assessment. Expert studies used in this paper and drawn up as part of the Strategy for the internalisation of external costs (Communication $\operatorname{COM}(2008)$ 435, 2008) aim to create supporting basis for general models for calculation of external costs of transport to be used for calculation of the amount of fees for the use of roads. 


\section{Materials and methods}

\subsection{Impacts and significance of negative externality of noise pollution}

Noise pollution generates costs for society as it causes inconvenience and has adverse effects on human body. It further causes disruption to concentration, learning disorders in children, sleep disorders and suchlike. If noise exceeds certain limit, it may increase the risk of occurrence of some health issues and have similar effects as stress (CE DELFT, 2011). Noise caused by various types of transport is a major environmental problem, which affects primarily densely populated, i.e. urban areas. Noise pollution is local and its nature is temporary and therefore the harm caused by noise depends on the quantity of people living or staying in the relative proximity to a noise source and on the conditions of spreading of noise to its surroundings. Unlike other externalities, noise causes immediate damage. Effects of permanent noise on people may accumulate and result in health problems. As stated in CE Delft (2008), hearing disorders may be caused by noise exceeding $85 \mathrm{~dB}$. Noise above $60 \mathrm{~dB}$ causes increased stress levels, higher blood pressure, heart rate and may result eventually in an increased risk of cardiovascular diseases. One of the major negative aspects caused by noise pollution is reduced sleep quality (CE DELFT, 2008)

The World Health Organization (WHO) adds tinnitus hearing disorder to the above mentioned effects; tinnitus manifests itself as hearing of constant "ringing" and cognitive learning disorder in children. WHO (2011) further states that transport noise pollution is the second major environmental stress factor, due to which every year more than one million of healthy life years are lost (these includes the years lost due to premature deaths and the years spent with disorders caused by noise pollution). Unlike other factors detrimental to the environment where people live, noise pollution is a factor with increasing effect on human lives. WHO (2009) further states that children, the elderly, pregnant women, the sick and shift workers are particularly at risk.

Further specific values follow from MPO (2015) data, in particular that noise exceeding $55 \mathrm{~dB}$ during the day impacts approximately 370,000 people and noise exceeding $40 \mathrm{~dB}$ at night almost 233,000 inhabitants of the Czech Republic.

According to WHO (2009) it is the level of night noise of $40 \mathrm{~dB}$ which has a demonstrable effect on human health. EEA (2016) states that up to 8 million inhabitants of Europe suffer from sleep disorders, 43,000 people are in hospitals and up to 10,000 premature deaths have been documented in connection with noise pollution generated by transport.

In terms of noise pollution the situation in Slovakia is substantially better. The Slovak Republic belongs to countries whose inhabitants are exposed to a lower degree of noise. It follows from the data presented in Chapter 3 of this paper that the number of people exposed to transport noise pollution is approximately one fourth of the number in the Czech Republic. Likewise, health and mental consequences associated with noise are much lower compared to the Czech Republic. As stated by EEA (2018a), while in the Czech Republic the number of people who suffer from sleep disorders due to transport is 400,000 , in Slovakia the number of people affected in this way is only 80,000; the same trend is apparent in the number of premature deaths associated with transport noise. In the Czech Republic, there are annually 500 deaths caused by transport noise; in Slovakia this number is ten times smaller, i.e. 50 persons whose death may be associated with transport noise. 
According to WHO (2018), road transport noise affects at least 100 million people in the European Union. WHO (2018) further strongly recommends that countries try to reduce road transport noise below $53 \mathrm{~dB}$ (weighted average value: day-evening-night) and below $45 \mathrm{~dB}$ at night. When these values are exceeded, it has negative impact on human health and healthy sleep. These facts then according to Pauhofova, Bukharbaeva and Egorova (2018) have negative impact on achieving of disposable income of people as good health is the factor positively affecting the growth of disposable income. According to the newest data from EEA (2018b), transport noise during the day exceeding $55 \mathrm{~dB}$ affects every fourth European citizen; at night, the level of annoying noise lowers to $50 \mathrm{~dB}$ and affects every sixth citizen of Europe.

Noise also depends on speed; noise grows with increased speed. According to CE Delft (2008), noise from road transport is generated primarily by the engine and friction on the carriage way. It is therefore apparent that heavy goods vehicles will generate more noise; besides their weight, the noise they generate also depends on their suspension, number of axles and number of trailers. In general, the amount of noise will also depend on the age and speed of a vehicle, type of carriage way (panels or cobbles are noisier), its slope and defects and the existence of noise barriers.

\subsection{European legislation of negative externalities of noise pollution}

Transport externalities and their minimization form an important point of European policies and many member states are trying to include these costs in their taxation systems or in various fee systems. According to Tuszyńska and Ratcliff (2018), transport policy was one of the first common European Union policies. An important aspect of creation of taxes and fees in the European Union should be that they efficiently and effectively remove the created externalities pursuant to the principle "user pays" and "polluter pays" and at the same time stimulate their reduction. This principle was defined by Directive 2006/38/EC which is a revision of the original Directive of the European Parliament and Council 1999/62/EC. These principles in the area of taxation and imposition of charges on transport are the objective of internalisation of negative externalities by including their costs in the paid taxes and road fees. As stated in Kenny (2017), Directive 2006/38/EC allows these charges in the form of performance fee to include a segment of external costs, i.e. the costs caused as a result of air or noise pollution. The fee for these external costs should be differentiated based on the type of road, vehicle category and also the time, so that it is possible to take into account the costs caused by transport noise. Appendix IIIb to the Directive of the European Parliament and Council 2011/76/EC then contain the parameters for calculation of maximum weighted average toll fee for external costs (air pollution and noise pollution).

The noise negative externality is directly dealt with in the Directive of the European Parliament and Council 2002/49/EC relating to the assessment and management of environmental noise. This Directive imposes an obligation on the member states of the European Union to analyze impact of environmental noise on population. The objective of the Directive is to eliminate, prevent or limit harmful and annoying impacts of environmental noise. The Directive stipulates the obligation of creation of noise maps, disclosing information to the public and implementation of action plans at the local level. In order to be able to secure international comparison, noise level is ascertained by common procedures and methods, in particular using noise indicators - descriptors. Descriptors are subsequently used for creation of the so-called noise maps which are used 
for clear visualisation of noise in the surroundings of main thoroughfares of road, rail and air transport and further also within major agglomerations. They are also suitable material for creation of anti-noise measures in the form of action plans aimed at solving of noise issue and its impacts and the possibility of its reduction. Strategic noise maps and noise action plans must be established at a five year interval and subsequently be submitted to the European Commission. Three stages have taken place so far - the first one in 2007, second one in 2012 and the last and third one was completed in 2017. However, King and Murphy (2016) point out that the first two stages are characterized by a relatively substantial data discrepancies and incompleteness, probably also due to low engagement of member states and their unwillingness to observe the specified procedures when measuring noise.

\subsection{Materials and methodology of measurement of external costs of transport noise pollution}

Quantification of the pecuniary cost of the negative externality of noise pollution is implemented based on thorough and in-depth analysis of methodologies of research studies prepared for this purpose for the European Committee. These include in particular the study of CE Delft expert and consultancy association called the "Handbook on estimation of external costs in the transport sector" of 2008 and the following and linked study prepared by Ricardo AEA strategic environmental company Ricardo AEA called "Update of the Handbook on External Costs of Transport" issued in 2014. The given studies were prepared as part of the Strategy for the internalisation of external costs (Communication $\operatorname{COM}(2008) 435$ ), which was a part of set of measures of the European Committee - the so called "Greening transport package" for the purpose of creation of a general model for calculation of external costs of transport, which might be used in the future for calculation of fees for the use of roads. The studies were indeed used for this purpose when calculating fees as part of amendment to Directive 1999/62/EC on the charging of heavy goods vehicles for the use of certain infrastructures in 2011.

The data concerning the number of inhabitants impacted by traffic noise were taken from the data published pursuant to Directive 2002/49/EC relating to the assessment and management of environmental noise, which imposes an obligation on member states to map the degree of noise exposure from main roads and within agglomerations. The information from the noise maps is then published by the European Environment Agency (EEA) and these data are used in this paper.

When measuring costs of negative externalities caused by noise pollution to affected population, it is necessary to take into account a number of factors. WHO (2011) states primarily the following factors:

- degree of exposure to noise established by technical measurement and the degree calculated or estimated,

- $\quad$ selection of suitable noise identifier,

- degree of population of area,

- daily regime of affected population,

- $\quad$ all sources of noise by which the given population is affected.

Of these above-mentioned factors CE Delft (2008) study states population density as the first most significant factor which causes the difference in noise pollution in urban and non-urban areas and the time of the day as the second most significant factor. Night noise causes potentially higher external costs to population - see Chapter 1 . The third 
factor affecting noise costs is the already existing degree of noise pollution which is significant particularly for measuring of marginal costs of noise. In a noisy area, the marginal costs for another noise unit will be small compared to a quiet area. From this point of view, the marginal costs associated with noise pollution are ascertained using the following factors:

- distribution and distance of the affected persons from the source of noise,

- $\quad$ existing noise level (traffic level prior to adding an additional unit - vehicle),

- $\quad$ time of the day (CE DELFT, 2008).

These three factors indicate that the marginal costs associated with noise are very variable and are given by local conditions and the time of the day or night. In general, marginal costs are higher at night when noise is more annoying and the background noise level is lower.

The actual imposition of charges of external costs of transport and determination of their correct amount faces a problem of which method is to be used for measuring of the particular external cost. The objective of all methods is determination of a particular assessment of a negative externality. Now, we will specify the methods used for assessment of costs of a negative externality. The most significant costs of externalities are social costs. Important factors affecting determinations of social costs are individual preferences of people. Individual preferences are classified as two basic approaches. These approaches are stated in CE Delft (2008) study and are divided as follows:

- willingness-to-pay (WTP) for improvement, willingness-to-pay is determined by the maximum amount a person is willing to pay for improvement of their situation or willing to give up in order to avoid an undesirable negative phenomenon,

- willingness-to-accept (WTA) compensation for situation without improvement, the willingness to accept compensation is given by the minimum amount for which the person is willing to give up the desired situation or which the person requests as compensation for acceptance of the unwanted negative impact.

According to CE Delft (2008) the methods used for assessment of social costs in relation to individual preferences of population are based on the use of representatives. Most often, such representative is GDP per capita. The assessment of willingness to pay is also determined by means of the method of stated preferences, which ascertains social costs by means of direct queries to individuals regarding their preferences. When assessing external costs, other methods are used which assess these costs with greater accuracy based on market value. However, if the market value of the given component of the external cost may not be ascertained, other methods are then used. These include a method of hedonic assessment, which is often used for assessment of housing value. The method consists in determination of the final value of real property, which is affected by its surroundings. This method thus takes into account not only the internal characteristics (real property condition and furnishing) but also the characteristics of the surroundings (environment, noise). The costs generated by the lower value of real property due to the poor condition of the surroundings then may be used for calculation of these externalities. The method of hedonic assessment was used in Delucchi and Hsu Shi-Lang (1998) study when determining external costs of noise pollution. Another method is the Impact pathway approach, which is used for assessment of externalities with a long-term impact (such as environmental damage due to global warming but also health costs due to longterm exposure to noise). The method takes into account direct and indirect costs necessary 
for rectification of the inflicted harm (and the harm which cannot be rectified) on human health and the environment (CE DELFT, 2008).

In order to assess external costs of noise, the said external studies use the methods of hedonic assessment based on the loss due to the decreased price of real estate caused by noisy environment or the method of stated preferences for assessment of social costs according to WTP approach. Further, impact pathway method is used, which uses WTP approach for assessment of human lives.

This paper, which focuses on measurement of external costs caused by noise, uses the value of unit costs per noise - see Table 3, which are stipulated based on WTP approach, health costs and costs of the loss of healthy life years, stated in Ricardo AEA (2014).

\section{Results}

\subsection{Measurement of total, average and marginal external costs of transport noise pollution in $C R$ and $S R$}

According to Ricardo AEA (2014), externality costs may be calculated using two approaches:

- $\quad$ bottom-up approach is based on specific traffic conditions and case studies; it is a more accurate calculation method with the possibility of differentiation but it is also a more demanding approach in terms of funds and time. The result of this approach is the determination of the value of marginal cost of an additional noise unit - in this case, the marginal cost of another vehicle added to traffic on the particular road,

- top-down approach uses total national data for calculation of average costs. This is a general approach, it allows comparison between various types of transport, however, comparison of particular transport conditions is rather difficult. The result of this procedure is the determination of average costs of negative externality. This average cost is calculated from the total costs of negative externality divided by the sum of transport performance of all vehicles (or transport performance of individual vehicles).

\subsection{Measuring total and average costs of noise pollution}

Measurement of externality costs is based on the specified unit price of the externality determined by means of the methods described above. In order to calculate the total and average external costs of transport noise pollution in the Czech Republic and the Slovak Republic, the following procedure is defined which was established as part of Developing Harmonised European Approaches for Transport Costing and Project Assessment study (IER, 2006). The calculation of the amount of total costs of noise pollution is implemented within the following steps:

1. quantification of the number of people exposed to noise pollution,

2. conversion of stated cost factors to the level of GDP for the given year,

3 . calculation of impact and calculation of total costs.

The total external costs of noise pollution may be calculated according to the following formula:

where:

$$
\mathrm{TEC}=\mathrm{PAN} * \mathrm{UEC}
$$


TEC - total external costs,

PAN (people affected by noise) - number of people affected by the given level of noise pollution,

UEC - (unit external cost) costs per one unit of noise emission.

Quantification of the number of people exposed to noise pollution may be determined using the data published in the noise maps defined in Chapter 2. The European Union introduced the obligation to publish the degree of noise exposure by means of noise maps in 2002 in its Directive 2002/49/EC. The Directive aims to fight noise pollution which affects people particularly in urban areas, in public parks or in quiet parts of agglomerations, in quiet parts in open countryside, near schools, hospitals and other sensitive buildings or areas. Two noise identifiers are established by this Directive $-\mathrm{L}_{\text {day }}$ and $\mathrm{L}_{\text {night. }} \mathrm{L}_{\text {day }}$ is an identifier of noise pollution for day, evening and night, $\mathrm{L}_{\text {night }}$ specifies sleep disturbing noise. We differentiate the affected areas to agglomerations, i.e. cities exceeding 100,000 inhabitants, main roads which are roads with more than 3 million cars per year and separate areas for major railways and airports.

In the Czech Republic, there are 3,521 km of roads meeting the conditions of a main road included in noise maps. Seven cities meet the agglomeration criteria of population above 100 000, in particular Praha, Brno, Olomouc, Ostrava, Plzeň, Liberec and Teplice (EEA, 2017). Table 1 presents the numbers of people exposed to transport noise divided to agglomerations and main roads including individual noise bands.

Table 1: Number of people in the CR exposed to transport noise according to $\mathrm{dB}$ bands

\begin{tabular}{|c|c|c|c|c|}
\hline \multicolumn{5}{|c|}{ Along main roads } \\
\hline \multicolumn{5}{|c|}{ Number of people exposed to noise according to $\mathrm{dB}$ bands $\left(\mathrm{L}_{\text {day }}\right)$} \\
\hline $55-59 d B$ & $60-64 d B$ & $65-69 d B$ & $70-74 d B$ & $>75 d B$ \\
\hline 388,300 & 162,800 & 115,300 & 56,300 & 3,000 \\
\hline \multicolumn{5}{|c|}{ Number of people exposed to noise according to dB bands ( $\left.\mathrm{L}_{\text {night }}\right)$} \\
\hline $50-55 d B$ & $55-59 d B$ & $60-64 d B$ & $65-69 d B$ & $>70 d B$ \\
\hline 229,500 & 126,700 & 70,400 & 9,200 & 200 \\
\hline \multicolumn{5}{|c|}{ Exposed to noise in agglomerations } \\
\hline \multicolumn{5}{|c|}{ Number of people exposed to noise according to dB bands $\left(\mathrm{L}_{\text {day }}\right)$} \\
\hline $55-59 d B$ & $60-64 d B$ & $65-69 d B$ & $70-74 d B$ & $>75 d B$ \\
\hline 830,400 & 495,300 & 287,500 & 145,500 & 9,000 \\
\hline \multicolumn{5}{|c|}{ Number of people exposed to noise according to dB bands ( $\left.\mathrm{L}_{\text {night }}\right)$} \\
\hline $50-55 d B$ & $55-59 d B$ & $60-64 d B$ & $65-69 d B$ & $>70 \mathrm{~dB}$ \\
\hline 542,500 & 309,800 & 177,500 & 21,900 & 500 \\
\hline
\end{tabular}

Source: EEA (2017)

It follows from the values stated in Table 1 that in total 725,700 people (indicator $\mathrm{L}_{\text {day }}$ ) in the Czech Republic are affected by transport noise exceeding $55 \mathrm{~dB}$ within the monitored roads (including all noise ranges); night noise (over $50 \mathrm{~dB}$ ) then affects 436,000 people ( $\mathrm{L}_{\text {night}}$ ). Compared to Czech main roads, the number of people affected by noise in Czech agglomerations is even higher. In all noise bands in agglomerations, 
transport noise exceeding $55 \mathrm{~dB}$ affects the total of 1,767,700 people ( $\left.\mathrm{L}_{\text {day }}\right)$; night noise exceeding $50 \mathrm{~dB}$ then affects $1,052,200$ people (EEA, 2017).

The number of persons affected along main roads in Slovakia is much lower which corresponds to the smaller number of kilometres of roads subject to noise mapping in line with Directive 2002/49/EC. While in the Czech Republic 3,521 km of roads are mapped, in Slovakia it is less than half this length, in particular $1595 \mathrm{~km}$ (EEA, 2017).

The data in Table 2 shows the numbers of people exposed to transport noise in agglomerations and along main roads including a division into individual noise bands in the territory of the Slovak Republic.

Table 2: Number of people in the SR exposed to transport noise according to dB bands

\begin{tabular}{|c|c|c|c|c|}
\hline \multicolumn{5}{|c|}{ Along main roads } \\
\hline \multicolumn{5}{|c|}{ Number of people exposed to noise according to dB bands ( $\left.\mathrm{L}_{\text {day }}\right)$} \\
\hline $55-59 d B$ & $60-64 d B$ & $65-69 d B$ & $70-74 d B$ & $>75 d B$ \\
\hline 95,900 & 47,700 & 18,300 & 2,900 & 800 \\
\hline \multicolumn{5}{|c|}{ Number of people exposed to noise according to dB bands ( $\left.\mathrm{L}_{\text {night }}\right)$} \\
\hline $50-55 d B$ & $55-59 d B$ & $60-64 d B$ & $65-69 d B$ & $>70 \mathrm{~dB}$ \\
\hline 70,400 & 25,200 & 7,600 & 900 & 0 \\
\hline \multicolumn{5}{|c|}{ Exposed to noise in agglomerations } \\
\hline \multicolumn{5}{|c|}{ Number of people exposed to noise according to dB bands $\left(\mathrm{L}_{\text {day }}\right)$} \\
\hline $55-59 d B$ & $60-64 d B$ & $65-69 d B$ & $70-74 d B$ & $>75 d B$ \\
\hline 156,400 & 114,400 & 63,500 & 19,400 & 8,100 \\
\hline \multicolumn{5}{|c|}{ Number of people exposed to noise according to dB bands ( $\left.\mathrm{L}_{\text {night }}\right)$} \\
\hline $50-55 d B$ & $55-59 d B$ & $60-64 d B$ & $65-69 d B$ & $>70 \mathrm{~dB}$ \\
\hline 126,500 & 68,900 & 23,500 & 8,600 & 1,700 \\
\hline
\end{tabular}

Source: EEA (2017)

It follows from the above data that transport noise above $55 \mathrm{~dB}$ along main roads affects 165,600 persons $\left(\mathrm{L}_{\text {day }}\right)$, night noise (over $50 \mathrm{~dB}$ ) then affects 104,100 persons $\left(\mathrm{L}_{\text {night }}\right)$ in total. Compared to the Czech Republic, the number of people exposed to noise $\left(\mathrm{L}_{\mathrm{day}}\right.$ and $\mathrm{L}_{\text {night}}$ ) is almost 4 times smaller. Even in agglomerations, the number of people affected is almost 5 times smaller than in the Czech Republic. This is given by the fact that in Slovakia there are only 2 cities meeting the agglomeration limit pursuant to Directive 2002/49/EC, namely Bratislava and Košice (compared to seven cities in the Czech Republic). Within these agglomerations, 361,800 people in all ( $\left.\mathrm{L}_{\text {day }}\right)$, and 229,200 at night ( $\left.\mathrm{L}_{\text {night }}\right)$ are exposed to noise pollution.

The actual calculation of the negative externality of noise pollution (following determination of the number of exposed persons) is implemented according to the following procedure. It is based on the identified number of people exposed to transport noise along main roads and along agglomerations stated in Table 1 and Table 2. The determined numbers of exposed people are for the purpose of quantification of total external costs of noise pollution subsequently multiplied by the annual unit noise pollution costs per person. These values of unit costs of the negative externality of noise pollution are stated in Table 3 . The unit costs were calculated based on previous studies on which Ricardo AEA (2014) is based and the result of which are summarized in detail in CE Delft study (2008). The stated unit costs were calculated by combining WTP 
(willingness-to-pay) approach which recommends using WTP costs of $0.09 \%-0.11 \%$ of GDP per $1 \mathrm{~dB}$ of generated noise for calculation of unit cost according to WTP and methods used for calculation of costs of the lost health life years of EUR 50,000-75,000 per one lost year of life, whereas this value corresponds to the statistical value of life of EUR 1 million. The last item of the unit cost of noise pollution are the health costs, which include the costs of cardiac infarction, angina pectoris, high blood pressure and health costs due to sleep disturbance. The resulting values according to the above-mentioned calculation method of noise unit costs are provided in Table 3. Table 3 presents the amount of noise unit cost for the Czech Republic and for the Slovak Republic as well. The amount of these costs is affected by the different amount of GDP per capita in the Czech Republic and in the Slovak Republic. For this reason the unit costs of noise in monitored countries differ and the procedure according to IER study (2006) is observed.

Table 3: Annual unit costs for transport noise pollution (in EURGDP2010) per person according to noise bands in the CR and SR

\begin{tabular}{lccccc}
\hline & $55-59 d B$ & $60-64 d B$ & $65-69 d B$ & $70-74 d B$ & $>75 d B$ \\
\hline Costs for CR & 19 & 38 & 57 & 76 & 127 \\
Costs for SR & 15 & 29 & 44 & 58 & 97 \\
\hline
\end{tabular}

Source: Ricardo AEA (2014)

The values stated in Table 3 are calculated for 2010 as they are based on the GDP per capita in 2010. Due to the calculation of external costs of noise pollution in 2017, the value of unit costs is converted to the level of 2017. The unit costs of noise pollution are increased by $14.6 \%$, whereas this value represents an increase of GDP per capita in the Czech Republic any by $19 \%$ - an increase of GDP per person in Slovakia according to data from EUROSTAT (2018). The unit costs of noise pollution for 2017 are calculated in Table 4.

Table 4: Annual unit costs for transport noise pollution (in EURGDP2017) per person according to noise bands in the CR and SR

\begin{tabular}{lccccc}
\hline & $55-59 d B$ & $60-64 d B$ & $65-69 d B$ & $70-74 d B$ & $>75 d B$ \\
\hline CR EUR $_{2017}$ & 22 & 44 & 65 & 87 & 146 \\
SR EUR $_{2017}$ & 18 & 35 & 52 & 69 & 115 \\
\hline
\end{tabular}

Determination of the amount of the total external costs is given by the formula (1) defined by authors. It is therefore multiplication of annual unit costs from Table 4 by the number of exposed people along main roads in Table 1 and Table 2 and the number of persons exposed to transport noise in agglomerations in Table 1 and Table 2 . The results of these measurements classified according to individual noise ranges are provided in Table 5 and Table 6. 
Table 5: Total costs of transport noise pollution in 2017 in CR (in EUR)

\begin{tabular}{lcccccc}
\hline & $55-59 d B$ & $60-64 d B$ & $65-69 d B$ & $70-74 d B$ & $>75 d B$ & Total \\
\hline $\begin{array}{l}\text { Costs per person } \\
\begin{array}{l}\text { Exposed people } \\
\text { along main roads }\end{array}\end{array}$ & 22 & 44 & 65 & 87 & 146 & \\
$\begin{array}{l}\text { Exposed people in } \\
\text { agglomerations }\end{array}$ & 830,400 & 162,800 & 115,300 & 56,300 & 3,000 & 725,700 \\
$\begin{array}{l}\text { Total costs along } \\
\text { main roads }\end{array}$ & $8,454,844$ & $7,089,614$ & $7,531,627$ & $4,903,505$ & 436,626 & $28,416,216$ \\
$\begin{array}{l}\text { Total costs in } \\
\text { agglomerations }\end{array}$ & $18,081,130$ & $21,569,324$ & $18,780,075$ & $12,672,468$ & $1,309,878$ & $72,412,875$ \\
Total costs & $26,535,974$ & $28,658,939$ & $26,311,702$ & $17,575,973$ & $1,746,504$ & $100,829,091$ \\
\hline
\end{tabular}

Table 6: Total costs of transport noise pollution in 2017 in SR (in EUR)

\begin{tabular}{lcccccc}
\hline & $55-59 d B$ & $60-64 d B$ & $65-69 d B$ & $70-74 d B$ & $>75 d B$ & Total \\
\hline Costs per person & 18 & 35 & 52 & 69 & 115 & \\
Exposed people along main roads & 95,900 & 47,700 & 18,300 & 2,900 & 800 & 165,600 \\
Exposed people in & 156,400 & 114,400 & 63,500 & 19,400 & 8,100 & 361,800 \\
agglomerations & $1,711,81$ & $1,646,12$ & & & & \\
Total costs along main roads & 5 & 7 & 958,188 & 200,158 & 92,344 & $4,608,632$ \\
& $2,791,74$ & $3,947,94$ & $3,324,86$ & $1,338,98$ & 934,983 & $12,338,51$ \\
Total costs in agglomerations & 0 & 4 & 0 & 8 & 5 \\
& $4,503,55$ & $5,594,07$ & $4,283,04$ & $1,539,14$ & $1,027,32$ & $16,947,14$ \\
Total costs & 5 & 1 & 8 & 6 & 7 & 7 \\
\hline
\end{tabular}

The resulting values for total external costs of noise pollution for the Czech Republic in 2017 amount to EUR 100,829 million. In the case of the Slovak Republic, the total external costs of transport noise pollution amount to EUR 16,947 million.

Further steps include division of total external costs of transport noise pollution according to individual groups of vehicles. In order to allocate total costs to individual types of transport, weight factors are used. These weight factors should reflect the different share in noise generation by different types of vehicles, whereas as is stated above, goods vehicles due to their very nature generate greater noise than passenger vehicles (CE DELFT, 2008). Besides the type of vehicle, the weight factors stated in Table 7 also differentiate between urban and non-urban areas. In both urban and nonurban areas the share of freight transport in total external costs of transport noise pollution exceeds $60 \%$, in particular $66 \%$ in urban areas (weight factors of freight transport including coaches, light duty vehicles and heavy goods vehicles amount altogether to 50.9 units of the overall 77.1 units delimiting road transport in Table 7), $63 \%$ in non-urban areas (17.2 units of total 27.4 weighted units of road transport). 
Table 7: Identified weight factors of transport type share in external costs of noise pollution

\begin{tabular}{lcc}
\hline & Urban & Non-urban \\
\hline Passenger vehicle - petrol & 1 & 1 \\
Passenger vehicle - diesel & 1.2 & 1 \\
Passenger vehicle LPG & 1 & 1 \\
Moped & 9.8 & 3 \\
Motorcycle & 1.2 & 4.2 \\
Bus & 9.8 & 3.3 \\
Light duty vehicle & 1.5 & 1.2 \\
Heavy goods vehicle below 12 t & 9.8 & 3 \\
Heavy goods vehicle over 12 t & 13.2 & 4.2 \\
Heavy goods vehicle with trailer & 16.6 & 5.5 \\
\hline Soure: IER $(2006)$
\end{tabular}

Source: IER (2006)

Of the total external costs of noise pollution along main roads in non-urban areas of EUR 28.416 mil. - see Table 5, freight transport in CR amounts to EUR 17.902 million; in urban areas (agglomerations) then of the total EUR 72.413 mil., freight transport is responsible for the above-mentioned $66 \%$ of external costs, i.e. EUR 47.793 mil. In total, the costs of negative externality of freight transport noise pollution in the Czech Republic in 2017 amounted to EUR 65.695 million. The calculation of average external costs per one kilometre travelled by a goods vehicle is implemented using the calculated values of total external costs caused by freight transport and the information about transport output of goods vehicles identified in both countries. In 2016, (newer data are not available as traffic in the CR is counted at 5-year intervals), freight transport accounted for $19 \%$ of transport performance in the Czech Republic, in particular its transport output was 9,918 million vehicle-kilometres - see Table 8.

Table 8: Transport performance according to category of vehicles in 2016 in CR (in billion vehicle-kilometres/year)

\begin{tabular}{lc}
\hline Total & 52.919 \\
Passenger vehicles & 42.619 \\
Heavy goods vehicles & 9.918 \\
Motorcycles & 0.383 \\
\hline
\end{tabular}

Source: RSD (2016)

The average cost of one vehicle-kilometre of goods vehicles is calculated at EUR 0.007 EUR (0.7 cent/vehicle-kilometre). However, this value represents the aggregated figure of all categories regarded as goods vehicles. In this case, it includes light duty vehicles, heavy duty vehicles below $12 \mathrm{t}$, heavy duty vehicles over $12 \mathrm{t}$, trucks with trailers and buses. Provided that detailed information was available regarding transport performance for particular goods vehicles categories, it would be possible to allocate total costs to individual vehicle categories. The average cost of noise would be higher for heavy trucks, smaller for light duty vehicles which generate less noise pollution. This statement may be supported even by the division of weight factors of the share of transport type in external costs stated in Table 7. 
Of the total external costs of noise pollution in Slovakia, the share of freight transport in total external cost along main roads amounts to EUR 2.904 mil.; in agglomerations, of the total EUR 12.339 million, freight transport is responsible for EUR 8.144 mil. In total, the costs of negative externality of freight transport noise pollution in Slovakia amount to EUR 11.048 million per year.

Table 9: Transport performance according to category of vehicles in 2015 in SR (in billion vehicle-kilometres/year)

\begin{tabular}{lc}
\hline Total & 25.650 \\
Passenger vehicles & 21.191 \\
Heavy goods vehicles & 4.318 \\
Motorcycles & 0.141 \\
\hline
\end{tabular}

Source: Slovenská správa ciest, Odbor cestnej databanky (2019)

The total transport performance of heavy goods vehicles in Slovakia in 2015 was 4,318 million vehicle-kilometres, i.e. half the value of heavy goods vehicle performance in the Czech Republic (again, newer data are not available due to the 5-year interval of counting traffic in the territory of the SR). In the case of the Slovak Republic, the average cost of one vehicle-kilometre of heavy goods vehicles is EUR 0.003 ( 0.3 cent/vehicle-kilometre). Compared to the average costs in the Czech Republic, this value is by $58 \%$ smaller.

\subsection{Marginal external costs of noise pollution}

Quantification of marginal costs of noise pollution uses a "bottom-up" approach, when based on specific conditions the marginal cost per vehicle-kilometre is determined plus the difference in harm per additional vehicle unit compared to the original condition is also determined. Ricardo AEA (2014) states marginal costs of noise pollution per vehiclekilometre for individual types of vehicles, various geographical areas, time of day, and traffic volume. Ricardo AEA (2014) uses as the basis for differentiation of marginal costs of noise pollution the German model of measurement of impact of noise on population described in Richtlinien für den Lärmschutzan Straßen (1990). The key factors when determining marginal costs include traffic volume (number of vehicles per hour), a share of heavy goods vehicles in the traffic flow (greater share of heavy goods vehicles in nonurban environment than in cities), average speed of vehicles on roads in the given environment (the maximum speed limit is higher in non-urban areas), distance of settlements from the road, percentage density of population in the given area and population of the given area expressed as the number of people per a kilometre of road.

Table 10 contains selected values of marginal costs classified for daytime traffic and urban areas (defined as population level $50 \%$ ). Further it contains the division between light traffic: 1,200 vehicles/hour and heavy traffic: 4,800 vehicles/hour. Values from Ricardo AEA (2014) study were again converted to prices in 2017 (increased GDP per capita in the CR by $14.6 \%$ and in the Slovak Republic by $19 \%$ compared to 2010 according to EUROSTAT (2018)). Marginal costs also fully reflect the above-mentioned facts - marginal cost per kilometre is greater for heavy goods vehicles, which generate greater noise impact than the more quiet light duty vehicles and marginal costs of noise pollution decrease with increasing traffic volume - the marginal cost of an additional 
noise unit is lower in an already noise polluted environment; conversely in a quiet environment, one additional vehicle causes much greater additional harm.

Table 10: Marginal costs of noise pollution (EUR/vehicle-kilometre) in CR and SR for selected vehicles, time of day, urban areas and the given traffic volume

\begin{tabular}{lccc}
\hline & & $C R$ & $S R$ \\
\hline \multirow{2}{*}{ Light duty vehicle } & light traffic & 0.0062 & 0.0060 \\
& heavy traffic & 0.0022 & 0.0021 \\
\hline \multirow{2}{*}{ Bus } & light traffic & 0.0062 & 0.0060 \\
\hline \multirow{2}{*}{ Heavy duty vehicle below 16 t } & heavy traffic & 0.0022 & 0.0021 \\
\hline
\end{tabular}

Source: Ricardo AEA (2014)

It follows from Table 10 that the marginal costs of noise pollution per kilometre for the selected vehicles in the given conditions are lower in all cases in Slovakia, which is caused by the conversion of average EU values according to the amount of GDP per capita. As this value is lower in the Slovak Republic, the respective marginal values are also lower than in the Czech Republic. However, CE Delft (2008) also states that marginal costs of noise pollution depend heavily on the specific conditions not only in the given state but also in the particular region in terms of density of population, already existing noise sources (not only transport), traffic volume, composition of traffic flow or changes in these factors during the day and at night. Mere conversion of marginal costs of noise pollution of the European Union (represented as a sort of an average for all European roads) to national values using the differences in GDP, as implemented above, only poorly represents the actual marginal costs, which might eventually differ from the values in Table 10. Moreover, it could well be that the marginal costs of transport noise pollution in the Slovak Republic are higher than in the Czech Republic, i.e. contrary to what is indicated in Table 10. As is clear from the facts and calculations stated above, the impact of noise pollution in Slovakia is much smaller than in the CR and the marginal costs of an additional noise unit in a more quiet environment is greater than the costs of an additional unit in the environment already exposed to noise pollution, where the marginal cost of noise is gradually decreased and not in a proportional manner.

The considerable dependence of marginal costs of noise pollution on local conditions eventually makes their practical use for internalisation of generated negative externality impossible. Although marginal costs this way better reflect the actual noise costs for exposed people, due to practical reasons of taxation policy the authors of this paper favour the use of average costs stated above. In terms of the actual form of the fiscal tool and based on the achieved results which reflect significant freight transport noise pollution in both countries, it is suitable to include the costs of the negative externality of noise pollution in the performance charges for goods vehicles, in particular because the legislation in this area was ready within the European Union as early as 2011.

\section{Conclusion}

The objective of this paper was to quantify (based on the defined methodology) the values of total, average and marginal costs of the negative externality of noise pollution in the Czech Republic and in the Slovak Republic. This measurement was based on 
Ricardo AEA (2014) and CE Delft (2008) expert studies drawn up for the European Commission as part of Strategy for the internalisation of external costs (Communication $\operatorname{COM}(2008) 435,2008)$. The objective of these studies was to create a general model for calculation of external costs generated by transport, which is to be subsequently used for calculation of fees for the use of roads in the EU. These studies were indeed used for this purpose during calculation of fees as part of amendment of Directive 1999/62/EC on the charging of heavy goods vehicles for the use of certain infrastructures, within the last amendment by Directive 2011/76/EU, which newly introduced the possibility of inclusion of external costs of noise pollution in these fees as part of further reinforcement of the "polluter pays" principle.

The practical application of inclusion of external costs of noise pollution is currently implemented only in Germany and Austria. In Germany, the part of the toll fee linked to the external cost of noise pollution is the same for all vehicles, in particular 0.2 cent per $\mathrm{km}$. This manner of determination of a toll fee in relation to negative externality does not reflect the above-mentioned fact that heavier and larger vehicles generate greater noise pollution than smaller vehicles. In Germany, the cost of noise pollution is also a part of the fiscal tool, in particular a road tax. Road tax is increased depending on inclusion of a heavy goods vehicle in vehicle emission category designated as G1.

In Austria, the additional fee for external costs of noise is applied by means of additional toll rate at night (from 22 to 5 hours), which reflects the fact (also stated in this paper) of increased harmful impact of noise at night. The amounts of noise charges differ according to the number of vehicle axles. All EURO classes of heavy goods vehicles with two axles will pay an external cost of noise of 0.04 eurocent per kilometre; vehicles with three axles will pay 0.092 cent; vehicles with four or more axles will pay 0.116 cent per kilometre. This graduation of toll fee rates better corresponds to the increasing noise emissions of large vehicles. However, unlike in Germany noise surplus to toll fee is smaller and it is paid only for night noise pollution.

It follows from the calculated assessment of negative externality of noise pollution generated by heavy goods vehicles that in both countries these units costs are high, in particular 0.7 cent/vehicle-kilometre in the Czech Republic and 0.3 cent/vehiclekilometre in the Slovak Republic. At the same time, the value of costs of noise pollution exceeds in both countries the maximum value of 0.2 cent/vehicle-kilometre stipulated by Directive 2011/76/EU, which may be applied as part performance charges of operation of heavy goods vehicles in EU membership states during the day on non-urban roads including motorways (at night the rate is specified at 0.3 cent/vehicle-kilometre). With regard to these facts and the existing legislation tools in the member states of the European Union, a suitable solution for internalisation of external costs of noise pollution seems to be application of performance charges for heavy goods vehicles on non-urban roads maximally up to 0.2 cent/vehicle-kilometre or 0.3 cent/vehicle-kilometre allowed by Directive 2011/76/EU. Although this would not result in full internalisation of negative externalities of freight transport noise pollution in the Czech Republic and the Slovak Republic calculated in this paper, it would still be a significant step in the given area.

It also follows from the results presented here that the discussion in both countries and intentions of member states to impose charges on external costs of noise pollution are justified and they are a desirable step leading to charging for generated external costs caused by freight transport. 


\section{References}

ACEA (2016). "ACEA Position Paper Reducing CO2.", Available from: https://www.acea.be/uploads/publications/ACEA_Position_Paper_Reducing_CO2_E missions_from_Heavy-Duty_Vehicles.pdf.

Ajanovic, A., Haas, R., Wirl, F. (2016). "Reducing CO2 emissions of cars in the EU: analyzing the underlying mechanisms of standards, registration taxes and fuel taxes", Energy Efficiency 9(4), pp. 925-937.

CE DELFT (2008). "Handbook on estimation of external costs in the transport sector: Internali-sation Measures and Policies for All external Cost of Transport (IMPACT) Versi-on 1.1.", Available from: https://ec.europa.eu/transport/sites/transport/files/themes/sustainable/doc/2008_costs_ handbook.pdf

CE DELFT (2011). "External Costs of Transport in Europe Update Study for 2008", Available from: http://ecocalctest.ecotransit.org/CE_Delft_4215_External_Costs_of_Transport_in_Europe_def.pdf.

Cnossen, S. (2005). Theory and Practice of Excise Taxation: Smoking, Drinking, Gambling, Pollution and Driving. (1th ed.) Oxford: Oxford University Press.

De Clerck, Q., Van Lier, T., Lebeau, P., Messagie, M., Vanhaverbeke, L., Macharis, C. Van Mierlo, J. (2016). "How Total is a Total Cost of Ownership?", World Electric Vehicle Journal 8(4), pp. 742 - 753.

Delucchi, M. A. (2003). "Environmental externalities of motor vehicle use", In: Hensher, D. A., Kenneth J. B.: Handbook of transport and the environment. Oxford: Elsevier.

Delucchi, M. A., Shi-Ling Hsu (1998). "External Damage Cost of Noise Emitted from Motor Vehicles", Journal of Transportation and Statistics 1, pp. 1 - 24.

EEA (2016). "Transport and public health", Available from: https://www.eea.europa.eu/signals/signals-2016/articles/transport-and-public-health.

EEA (2017). "Reported data on noise exposure covered by Directive 2002/49/EC.", Available from: https://www.eea.europa.eu/data-and-maps/data/data-on-noiseexposure-6.

EEA (2018a). "Noise country factsheets", Available from: https://www.eea.europa.eu/themes/human/noise/noise-fact-sheets.

EEA (2018b). "The NOISE Observation \& Information Service for Europe”, Available from: http://noise.eea.europa.eu.

EUROSTAT (2018). "Real GDP per capita", Available from: https://ec.europa.eu/eurostat/web/products-datasets/-/sdg_08_10.

Frouzova, K., Vachal, A. (2019). "Ministerstvo dopravy připravuje zdražení mýta. Zavedením poplatku za hluk a ekologii ho bude moci zvýšit až o polovinu", Available from: https://archiv.ihned.cz/c1-66557610-statu-se-otevira-cesta-ke-zdrazeni-mytazavedenim-poplatku-za-hluk-a-ekologii-by-ho-mohl-zvysit-az-o-polovinu.

Hamad, K., Khalil M., Shanableh A. (2016). "Developing free-field roadway traffic noise predictive model for Sharjah City, United Arab Emirates", Advances in Transportation Studies an international Journal 40, pp. 69-86. doi: 10.4399/97888548970076.

IER (2006). "Developing Harmonised European Approaches for Transport Costing and Project Assessment. Deliverable 5 ProposalforHarmonisedGuidelines", Available from: http://www.putevi-srbije.rs/images/pdf/strategija/HEATCO_D5_eng.pdf.

Johnson, P., Leicester, A., Stoye, G. (2012). "Fuel for Thought, The what, why and how of motoring taxation", Available from: 
https://pdfs.semanticscholar.org/13dd/aec1d6b96f4a8b2bbb0ba443c82fde78ab9f.pdf? $\mathrm{ga}=2.17453817 .1199199990 .1562085859-1119914416.1562085859$.

Kenny, S. (2017). "The Economic Impacts of Road Tolls.", Available from: https://www.transportenvironment.org/sites/te/files/publications/2017_04_road_tolls_ report_briefing.pdf.

King, E. A., Murphy, E. (2016). “Environmental noise - 'Forgotten' or 'Ignored' Pollutant?", Applied Acoustics 112, pp. 211-215.

Lebeau, K., Lebeau, P., Macharis, C., Van Mierlo, J. (2013). "How expensive are electric vehicles? A total cost of ownership analysis", "World Electric Vehicle Journal" 6(4), pp. 996-1007.

Palenik, V., Miklosovic, T. (2018). "Concept of Environmental Taxes as EU's Own Resource and CGE Modelling of its Effects on Slovakia", Journal of Economics 66(3), pp. $268-285$.

Pauhofová, I., Bukharbaeva, L., Egorova J. (2018). "Evaluation of Health Influence upon an Individual's Income", Journal of Economics 66(10), pp. 1051 - 1064.

Pigou, A. C. (1932). "The Economics of Welfare". London: Macmillan, Available from: https://oll.libertyfund.org/titles/pigou-the-economics-of-welfare.

Ricardo AEA (2014). "Update of the Handbook on External Costs of Transport", Available from: https://ec.europa.eu/transport/sites/transport/files/themes/sustainable/studies/doc/2014 -handbook-external-costs-transport.pdf.

Richtlinienfür den LärmschutzanStraßen (1990). "Richtlinienfür den LärmschutzanStraßen", Available from: https://www.gesund-am-stienitzsee.de/wpcontent/uploads/RLS90-opt.pdf.

Rozehnalová, H., Mádr, M., Formanová, L., Andrlík, B. (2021). “Influence of Pollutants from Transport on Life Expectancy in the EU Countries". Problemy Ekorozwoju 16(1), pp. 209-217. ISSN 1895-6912.

RSD (2016). "Celostátní sčítání dopravy na dálniční a silniční síti ČR v roce 2016", Available from: http://silnicniseminar.cz/files/Kubesova-Celostatni-s-itani-dopravy2016.pdf.

Santos, G. et al. (2010). "Externalities and Economic Policies in Road Transport", Research in Transportation Economics 28(1), pp. 2 - 45.

Slovenská správa ciest, Odbor cestnej databanky (2019). "Dopravní výkon dle kategorie vozidel v roce 2015 ". internal data.

Treaty establishing the European Economic Community (1957). Treaty establishing the European Economic Community, Available from: https://eur-lex.europa.eu/legalcontent/DE/TXT/PDF/?uri=CELEX:11957E/TXT\&from=CS.

Tuszyńska, B., Ratclif, Ch. (2018). "Společná dopravní politika: obecné zásady", Available from: http:/www.europarl.europa.eu/factsheets/cs/sheet/123/spolecnadopravni-politika-obecne-zasady.

WHO (2009). "Night noise guidelines for Europe", Available from: http://www.euro.who.int/_data/assets/pdf_file/0017/43316/E92845.pdf?ua=1.

WHO (2011). "Burden of disease from environmental noise: Quantification of healthy life years lost in Europe", Available from: https://www.who.int/quantifying_ehimpacts/publications/e94888.pdf?ua=1.

WHO Regional Office For Europe (2018). "Environmental Noise Guidelines for the European Region”. Copenhagen: WHO Regional Office for Europe. 
European Transport $\backslash$ Trasporti Europei (2021) Issue 83, Paper n 8, ISSN 1825-3997

Acknowledgments

This paper was supported by the Technology Agency of the Czech Republic - TACR Environment of life 3, SS03010156. 